\title{
Survey and Status of Different Diseases of Cotton under South Gujarat Region, India
}

\author{
Prashant B. Sandipan*, G.R. Bhanderi, R.D. Patel and B.G. Solanki \\ Main Cotton Research Station (MCRS), Navsari Agricultural University (NAU), \\ Surat 395007 Gujarat, India \\ *Corresponding author
}

\section{A B S T R A C T}

\section{Keywords}

Cotton, Survey, Intensity, Pest, Disease.

\section{Article Info}

Accepted:

19 July 2017

Available Online:

10 September 2017
In this experiment, different districts of South Gujarat were closely examined for various diseases in different cultivars. A roving survey was conducted on cultivars' field during the crop season and a fix point survey on cotton was conducted periodically at Research farm. On Research farm, periodical observations were recorded on G. Cot. Hy. 12 which revealed that bacterial blight appeared during the $2^{\text {nd }}$ week of July $(2.0 \%)$ and then gradually developed and reached at its peak (23.5\% PDI) during the $3^{\text {rd }}$ week of September and then declined, but prevailed up to $1^{\text {st }}$ week of December. Observations were also recorded on other cultivars. The susceptible cultivars viz., LRA 5166 showed bacterial blight intensity to the tune of 2.5 to 23.0 per cent PDI moreover, non Bt cotton was more susceptible to the bacterial blight disease. During 30 - 45 DAS (vegetative stage of the crop), the BLB was more pronounced on lower leaves. Roving survey was conducted in Surat, Bharuch and Narmada districts on farmers' field. The BLB incidence was found in the range of 0.0 to $5.5 \%, 0.0$ to $3.0 \%$ and 0.0 to $24.0 \%$ PDI in Surat, Bharuch and Narmada districts, respectively on fields, majority of them were growing approved BG II hybrids. Moreover, Alternaria leaf spot was observed in the range of 0.0 to $13.5 \%$ in Nandod taluka of Narmada district (Kuta Amba village). Whereas, in other two districts viz., Surat and Bharuch, it was in the tune of 0.0 to $2.0 \%$ and $0.0 \%$ PDI, respectively.

\section{Introduction}

Cotton is a very economical, commercial and important crop in India and predominantly used world over with attention. Cotton "The White Gold" aggregates a pre-eminent status and role among all the cash crops in the country and is the foremost raw material for a thriving textile industry. Proper awareness with the emphasis on crop improvement, crop production techniques, crop protection technologies and value addition are of the overriding importance in ensuring sustainability of cotton production and also livelihood security for the farmers. The crop is affected by numerous pests, diseases and weeds etc causing serious economic losses. In the pre Bt cotton era (Before 2002) the boll worm complex led by American boll worm Helicoverpa armigera almost entirely damaged the cotton crop if left unprotected. In the post Bt cotton era (2002 onwards) sucking pests like Aphids, Jassids, Thrips, Whitefly, Mealybugs, Myrid bugs and Mites 
continue to ravage the cotton crop and pose a serious threat to sustain and enhance cotton productivity (Tanweer, 2013). In India, 30 diseases have been reported for cotton crop. Out of these, 17 are caused by pathogens of fungal origin, four of bacterial nature, two are of nematodes and many known and unknown viruses and physiological disorders (Sekhon et al., 2008).

Among the diseases, Bacterial blight caused by Xanthomonas malvacearum and boll rot complex is the major constraints. This pathogen infects almost all crop stages and causes considerable loss in the seed cotton yield, seed index, oil percentage and ginning out turn (Meshram and Raj, 1988 and Shelke et al., 2012). The bacterial blight is the most wide spread and destructive disease reported to cause yield losses of about 10 to 30 per cent (Kalpana et al., 2004, Mishra, Krishna, 2001 and Sandipan et al., 2016) and also affect the quality of lint (Sharma and Chauhan, 1985).

Under natural bacterial blight infection, boll yield losses up to $35 \%$ have been reported (Sheoraj and Verma, 1988). Bacterial leaf blight, boll rots, wilts and leaf spots are the most destructive cotton diseases and are also known to cause considerable losses in yield (Chopra, 1977 and Bashi et al., 1983).

Continuous rain and moist condition, injudicious use of nitrogen fertilizer and irrigation create most favourable condition for the fungal foliar diseases. Losses due to Alternaria leaf spot (26.6\%), grey mildew (29.2 \%) and Myrothecium leaf spot (29.1\%) have been reported.

This overall situation leads to felt a closer examination of the diseases those were present on cotton crop under South Gujarat region, hence systemic investigation on various diseases were carried out.

\section{Major diseases of cotton}

Bacterial blight (Xanthomonas campestris pv malvacearum (Smith) Dye), Maharashtra, Gujarat, Karnataka

Cotton leaf curl (Gemini virus), North zone (Potential threat)

Alternaria leaf spot (Alternaria macrospora Zimm.), Maharashtra, Gujarat, Karnataka

Grey mildew (Ramularia areola Atk.), Central \& South zone (Emerging)

Myrothecium leaf spot (Myrothecium roridum Tode ex Fr.), Madhya Pradesh

Leaf Rust (Phakopsora gossypii (Arth) Hirat F.), Karnataka, Andhra Pradesh (Emerging)

Cercospora leaf spots (Cercospora gossypina Southw.), Andhra Pradesh (Minor)

Helminthosporium leaf spot (Helminthosporium spiciferum (Bain) Nicot.), Andhra Pradesh (Minor)

Anthracnose (Colletototricum gossypsii Southw.), South zone (Minor)

Tobacco streak virus (Ilar virus), Andhra Pradesh (Emerging)

Wilt (Fusarium oxysporum f. sp.vasinfectum (Atk.) Snyder and Hansen), Restricted to diploids

New wilt/sudden wilt (Parawilt)

Root rot (Rhizoctonia solani Kuhn, $R$. bataticola (Taub) Butler), Scattered Leaf reddening

Verticillium wilt (Verticillium dahliae Khleb.), Tamil Nadu, Karnataka 


\section{Materials and Methods}

In South Gujarat region, survey of the major diseases of cotton crop was carried out in different fields in various districts. Bt cotton fields from different areas were selected randomly on the survey route. In each field, plants were selected at random and the severity for different diseases was recorded. The range of severity of disease intensity was calculated for foliar diseases as the incidence of particular disease in their respective areas.

Five leaves from lower part and 5 leaves from middle/ plant were selected by using 0-4 scale as given by (Sheoraj, 1989) and then these grades were converted into per cent disease intensity (PDI) by using the formula given by Wheeler (1969).

No. of infected plants

Disease incidence $(\%)=$

No. of leaves observed x Max. Grade

\section{Results and Discussion}

A roving survey was conducted on cultivars' field during the crop season and a fix point survey on cotton was conducted periodically at Research farm.

On Research farm, periodical observations were recorded on G. Cot. Hy. 12 which revealed that bacterial blight appeared during the $2^{\text {nd }}$ week of July $(2.0 \%)$ and then gradually developed and reached at its peak (23.5 \% PDI) during the $3^{\text {rd }}$ week of September and then declined, but prevailed up to $1^{\text {st }}$ week of December. Observations were also recorded on other cultivars. The susceptible cultivars viz., LRA 5166 showed bacterial blight intensity to the tune of 2.5 to 23.0 per cent PDI moreover, non $B t$ cotton was more susceptible to the bacterial blight disease. During 30 - 45 DAS (vegetative stage of the crop), the BLB was more pronounced on lower leaves (Table 1 and Graph 1).

Table.1 Observations on the occurrence of the diseases

(In farmers' field and research farm) during 2015-16

\begin{tabular}{|c|c|c|c|c|c|c|c|}
\hline \multirow{2}{*}{$\begin{array}{l}\text { Sr. } \\
\text { No. }\end{array}$} & \multirow[t]{2}{*}{ District } & \multirow[t]{2}{*}{ Taluka } & \multirow{2}{*}{$\begin{array}{l}\text { Location/ } \\
\text { Village }\end{array}$} & \multirow[t]{2}{*}{ Month } & \multirow{2}{*}{$\begin{array}{c}\text { Variety/ Hybrid/ } \\
\text { cultivars }\end{array}$} & \multicolumn{2}{|c|}{ Disease (PDI) } \\
\hline & & & & & & BLB* & ALS* \\
\hline \multirow[t]{7}{*}{1} & \multirow[t]{7}{*}{ Surat } & \multirow[t]{5}{*}{ Choryasi } & \multirow[t]{5}{*}{ MCRS, Surat } & \multirow{5}{*}{$\begin{array}{l}\text { September } \\
\text { - October }\end{array}$} & G. Cot. Hy.6 BG II & $0.0-1.5$ & $0.0-1.0$ \\
\hline & & & & & G. Cot. Hy.8 BG II & $0.0-2.0$ & $0.0-1.0$ \\
\hline & & & & & LRA 5166 & $2.5-23.0$ & $1.0-3.0$ \\
\hline & & & & & Suraj & $3.5-12.5$ & $0.0-4.5$ \\
\hline & & & & & G. Cot. Hy.12 & $2.0-23.5$ & $0.0-1.0$ \\
\hline & & \multirow[t]{2}{*}{ Mangrol } & Chandaniya & \multirow[t]{2}{*}{ September } & Ajeet 155 BG II & $1.5-5.5$ & $0.0-2.0$ \\
\hline & & & Vasrayi & & Vikram 5 BG II & $0.0-1.5$ & $0.0-1.0$ \\
\hline \multirow[t]{5}{*}{2} & \multirow[t]{5}{*}{ Bharuch } & \multirow[t]{3}{*}{ Valiya } & \multirow[t]{3}{*}{ Sodgam } & \multirow[t]{3}{*}{ September } & RCH-2 BG II & $0.0-2.0$ & 0.0 \\
\hline & & & & & Nuzuvedu-199 & $0.0-2.5$ & 0.0 \\
\hline & & & & & Nath-155 & $0.0-2.0$ & 0.0 \\
\hline & & \multirow[t]{2}{*}{ Valiya } & \multirow[t]{2}{*}{ Tuna } & \multirow[t]{2}{*}{ September } & RCH-2 BG II & $0.0-1.9$ & 0.0 \\
\hline & & & & & Ankur - 3028 & $1.0-3.0$ & 0.0 \\
\hline \multirow[t]{5}{*}{3} & \multirow[t]{5}{*}{ Narmada } & \multirow[t]{2}{*}{ Nandod } & \multirow[t]{2}{*}{ Kuta Amba } & \multirow[t]{2}{*}{ September } & Ajeet BG II & $15.0-24.0$ & $5.0-13.5$ \\
\hline & & & & & RCH-2 BG II & $5.0-12.5$ & 0.0 \\
\hline & & \multirow[t]{3}{*}{ Netrang } & Chitrawadi & September & RCH-2 BG II & $0.0-5.0$ & 0.0 \\
\hline & & & Kambodia & September & Ajeet BG II & $1.0-8.0$ & 0.0 \\
\hline & & & Kelikuva & September & Ajeet BG II & $1.0-5.5$ & $0.0-2.5$ \\
\hline
\end{tabular}

*Bacterial leaf blight (BLB)

*Alternaria leaf blight (ALB) 
For, Bacterial leaf blight (BLB) disease

\begin{tabular}{|c|l|}
\hline Score & Description \\
\hline 0 & DF= Immune, completely free from bacterial blight \\
\hline 1 & $\begin{array}{l}\text { R= Resistant, nearly } 1 \mathrm{~mm} \text { in diameter, not coalescing, reddish, not } \\
\text { angular, veins free }\end{array}$ \\
\hline 2 & MR= Moderately resistant, leaf area covered up to 2- $10 \%$ \\
\hline 3 & $\mathrm{MS}=$ Moderately susceptible, infection 11-20\% \\
\hline 4 & $\mathrm{~S}=$ Susceptible, infection more than $20 \%$ \\
\hline
\end{tabular}

For, Alternaria leaf spot (ALS) disease

\begin{tabular}{|c|l|}
\hline Score & Description \\
\hline 0 & No infection \\
\hline 1 & Few < 2mm, scattered, brown spots, < 5 leaf area covered \\
\hline 2 & Spots bigger, 3 mm, not coalescing, brown and 6-20\% leaf area covered \\
\hline 3 & Spots 3-5 mm, irregular in shape-coalescing, 21-40\% leaf area covered \\
\hline 4 & $\begin{array}{l}\text { Spots coalescing to form bigger lesions, irregular }>40 \% \text { leaf area } \\
\text { covered }\end{array}$ \\
\hline
\end{tabular}

Word cloud from Introduction

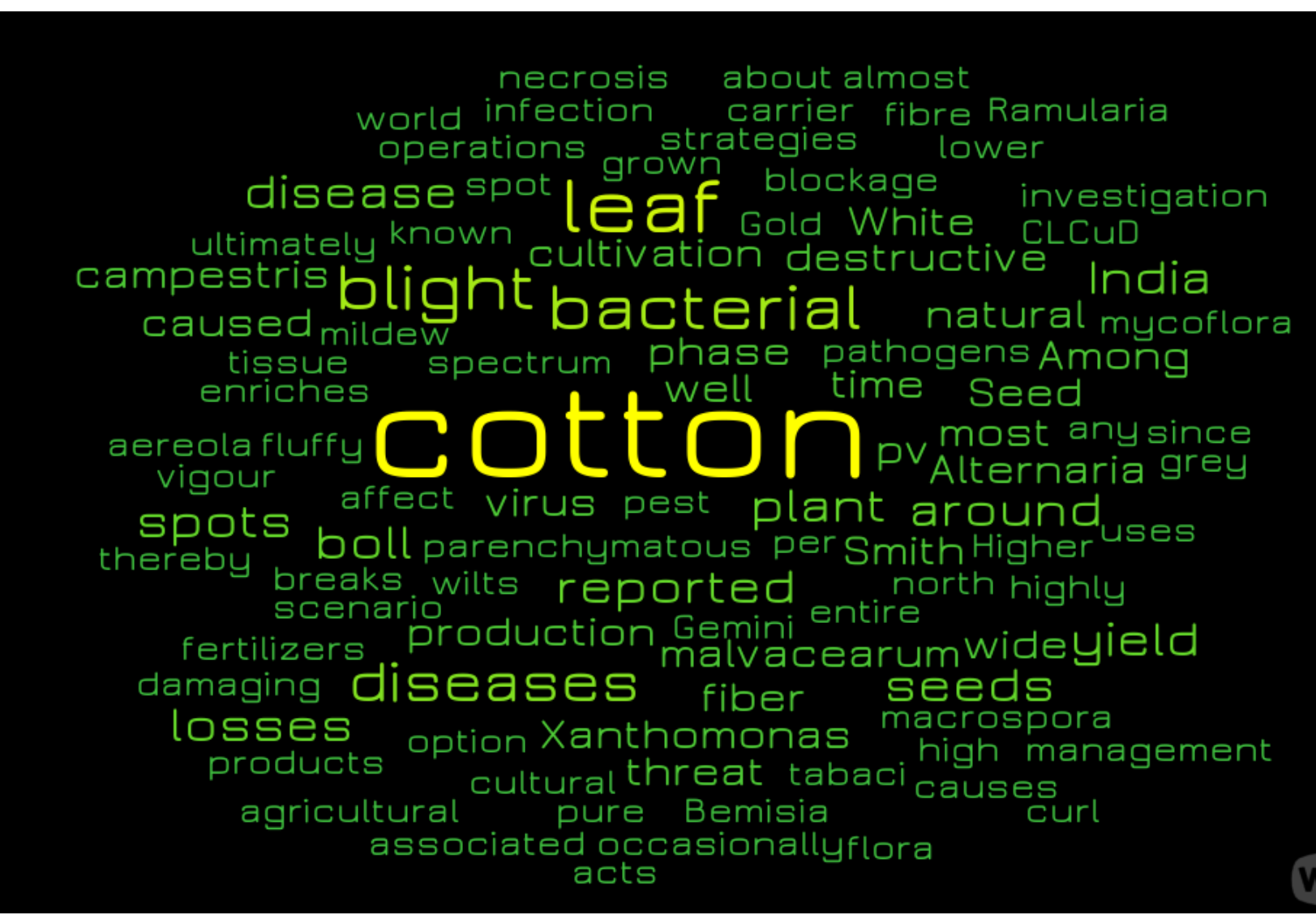


Graph.1 Shows the Bacterial blight intensity, PDI. (Maximum range was taken)

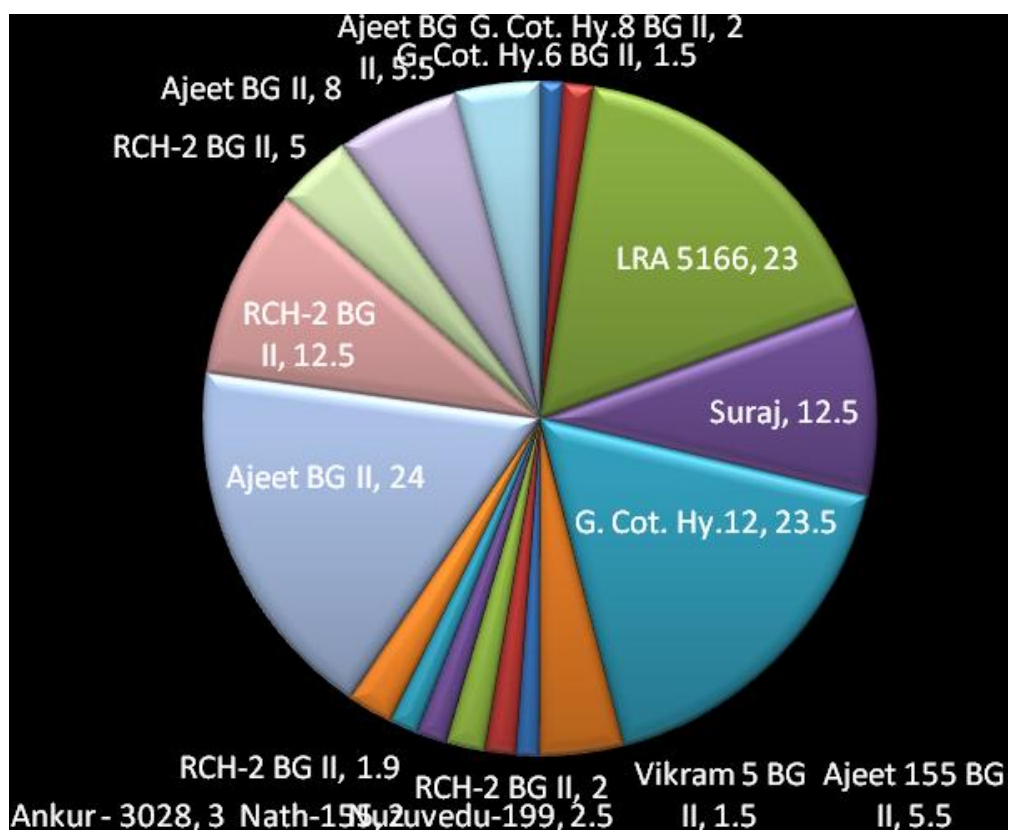

Graph.2 Shows the Alternaria leaf blight, PDI. (Maximum range was taken)

\section{Disease}
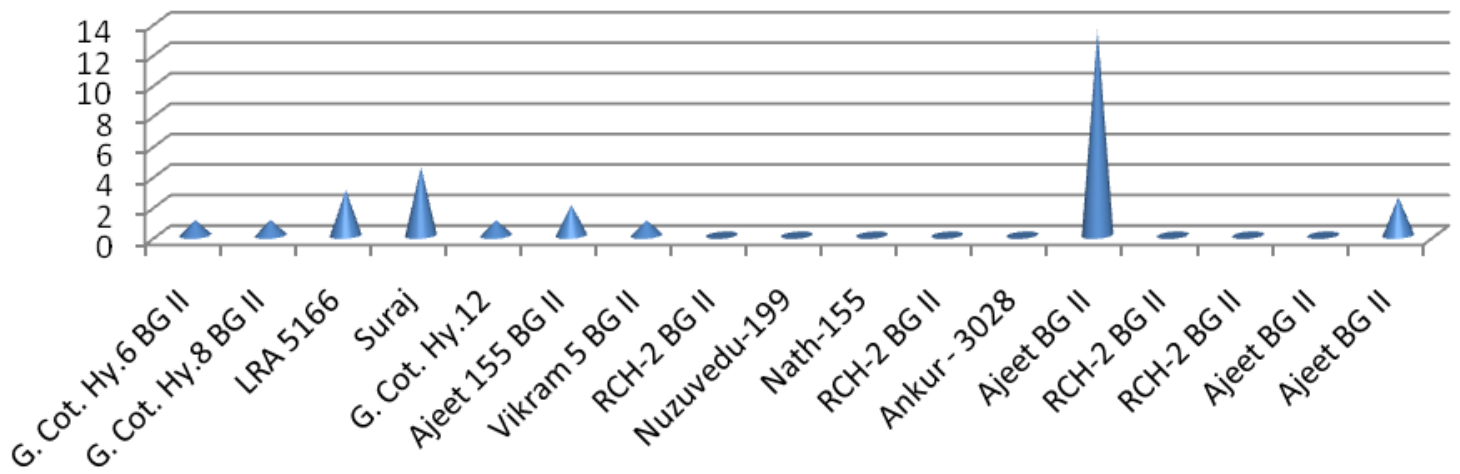

Roving survey was conducted in Surat, Bharuch and Narmada districts on farmers' field. The BLB incidence was found in the range of 0.0 to $5.5 \%, 0.0$ to $3.0 \%$ and 0.0 to $24.0 \%$ PDI in Surat, Bharuch and Narmada districts, respectively on fields, majority of them were growing approved BG II hybrids. Moreover, Alternaria leaf spot was observed in the range of 0.0 to $13.5 \%$ in Nandod taluka of Narmada district (Kuta Amba village). Whereas, in other two districts viz., Surat and Bharuch, it was in the tune of 0.0 to $2.0 \%$ and $0.0 \%$ PDI, respectively (Graph 2).

\section{Acknowledgement}

Author is highly thankful to Main Cotton Research Station (MCRS), NAU, Surat 
(Gujarat) for providing the required facility and other necessary arrangements for the facilitating the experiment.

\section{References}

Bashi, E., Sachs, Y. and Rotem, J. 1983. Phytoparasitica, 11: 89-97.

Chopra, B.L., 1977. Important diseases of cotton and their control measures in India. Paper presented at staff course on cotton production, its processing and marketing technology held at P.A.U., Ludhiana.

Kalpana, P., Chellamuthu, V. and Jeyalakshmi, C. 2004. Screening of cotton hybrids against bacterial blight incited by Xanthomonas campestris pv. malvacearum (Smith) Dye, Paper presented in Inter. Symp. Strat. Sust. Cotton Prod. - A Global Vision 3, Crop Production, 23-25 November 2004, Univ. Agric. Sci., Dharwad (India), pp. 373-374.

Meshram, M.K. and Sheo, Raj. 1988. Assessing losses due to bacterial blight diseases. Plant Pathology. The Tata McGraw Hill Publ. Co. Ltd., New Delhi, pp. 315.

Mishra, S.P., and Krishna, A. 2001. Assessment of yield potential losses due to bacterial blight of cotton. Journal of Mycology and Plant Pathology, 31: 232-233.

Prashant, B., Sandipan, Bhanderi, G.R., Patel, R.D., Desai, H.R. and Solanki, B.G. (2016). Survey and occurrence of different diseases of cotton in cultivators' and farmers field under South Gujarat condition. Int. J. Plant Sci., 1 (2): 278-281.

Sekhon, P. S., Singh, D. and Singh, G. 2008. Cotton pathology research achievements and targets in Punjab. All India Coordinated Cotton Improvement Project Report. PAU, Ludhiana.

Sharma, B.K., and Chauhan, M. S. 1985. Studies on the chemical control of foliar diseases of cotton in Haryana state. Agric. Sci. Digest. 5: 153-56.

Shelke, G. V., Aurangabadkar, L. P., Kashikar, A. R., Wadyalkar, S. R., Phalak, M. S., Khsrkar, H. H. and Umslkar, G. V. 2012. Identification of resistance source for Bacterial blight disease caused by Xanthomonas axonopodis pv. malvacearum and its genetic inheritance in upland cotton. Cotton Research Journal, 3 (2): 167173.

Sheoraj, 1989. Grading system for cotton disease. CICR Publication, Nagpur.

Sheoraj, and Verma, J. P. 1988. Diseases of cotton in India and their management. Review of Tropical Plant Pathology, 5: 207-254.

Tanweer, Asif. 2013. Pesticides in Cotton The Road Ahead. National convention on India cotton: Gearing up for Global leadership. Pp. P 9-11.

Wheeler, B. E. J., 1969. An Introduction of Plant Disease, John Wiley and Sons Limited, London, p. 301.

\section{How to cite this article:}

Prashant B. Sandipan, G.R. Bhanderi, R.D. Patel and Solanki, B.G. 2017. Survey and Status of Different Diseases of Cotton under South Gujarat Region, India. Int.J.Curr.Microbiol.App.Sci. 6(9): 1362-1367. doi: https://doi.org/10.20546/ijcmas.2017.609.165 